\title{
Seed Quality of Coriander as Affected by Irrigation and Fertilizer Levels
}

\author{
Harshita Singh, V.P.S. Panghal*, V.S. Mor and M.K. Rana \\ Chaudhary Charan Singh Haryana Agricultural University, Hisar-125004, Haryana, India \\ *Corresponding author
}

\section{A B S T R A C T}

\begin{tabular}{|l|}
\hline Ke y w or d s \\
Coriander, \\
Irrigation, Fertilizer \\
levels, Seed quality. \\
\hline Article Info \\
\hline Accepted: \\
04 October 2017 \\
Available Online: \\
10 December 2017 \\
\hline
\end{tabular}

The experiment conducted during 2014-15 comprised of four irrigation schedules, i.e., $\mathrm{I}_{1}\left(25\right.$ and 50 DAS), $\mathrm{I}_{2}\left(25,50\right.$ and 75 DAS), $\mathrm{I}_{3}(25,75$ and $100 \mathrm{DAS})$ and $\mathrm{I}_{4}$ $(25,50,75$ and $100 \mathrm{DAS})$ and three fertilizer levels, i.e., $\mathrm{F}_{1}\left(\mathrm{~N}_{45}\right.$ and $\left.\mathrm{P}_{37.5} \mathrm{~kg} / \mathrm{ha}\right)$, $\mathrm{F}_{2}\left(\mathrm{~N}_{60}\right.$ and $\left.\mathrm{P}_{50} \mathrm{~kg} / \mathrm{ha}\right)$ and $\mathrm{F}_{3}\left(\mathrm{~N}_{75}\right.$ and $\left.\mathrm{P}_{62.5} \mathrm{~kg} / \mathrm{ha}\right)$. The quality of coriander seeds harvested from various irrigation and fertilizer treatments was evaluated in Seed Testing Laboratory. The results revealed that seed produced under $\mathrm{I}_{4}(25,50,75$ and 100 DAS) irrigation schedule and $\mathrm{F}_{2}\left(\mathrm{~N}_{60}\right.$ and $\left.\mathrm{P}_{50} \mathrm{~kg} / \mathrm{ha}\right)$ fertilizer level gave the best quality seeds with higher 1000 seed weight $(\mathrm{g})$, standard germination (\%), seedling length $(\mathrm{cm})$, seedling dry weight $(\mathrm{mg})$, seedling vigour index-I, seedling vigour index-II and seed density $(\mathrm{g} / \mathrm{cc})$ as compared to other irrigation and fertilizer treatments but with minimum electrical conductivity values.

\section{Introduction}

Coriander (Coriandrum sativum L.), a member of umbelliferae family, is cultivated for its high commercial value of stems, leaves and seeds and considered as natural source of essential oils, i.e., petroselinic acid, geraniol, limonene and linalool, used in pharmaceutical and food industries (Carrubba, 2009; Hassan and Ali, 2013). It is appreciated worldwide as basic ingredient in many traditional food items, particularly curry powder because of its strong and typical aroma (Ramadan and Morsel, 2002; Mahendra and Bisht, 2011; Sahib et al., 2013). India is the largest producer and acreage holder of this crop, covering 563 thousand hectares area and giving production of 462 thousand tonnes during the year 2014-15 (Anonymous, 2015). Despite its importance, the productivity of coriander in India continues to be low which may be ascribed to many reasons, of which, availability of quality seed is one of the major factors. Quality seed is the basic unit for releasing higher yield per unit area. The management of irrigation and fertilizers is key factor to attain the seed quality of any crop.

The quality seed not only enables the farmers to take economic decisions regarding cost of seed but also helps them to have idea about the quality of seed to plant, uniformity of plant stand and consequently the net returns.

Therefore, the availability of genetically pure and vigorous seed at planting time is important for achieving target of agriculture production. 


\section{Materials and Methods}

The experiment conducted during 2014-15 comprised of four irrigation schedules, i.e., $\mathrm{I}_{1}$ (25 and 50 DAS), $\mathrm{I}_{2}\left(25,50\right.$ and 75 DAS), $\mathrm{I}_{3}$ (25, 75 and 100 DAS) and $\mathrm{I}_{4}(25,50,75$ and 100 DAS) and three fertilizer levels, i.e., $\mathrm{F}_{1}$ $\left(\mathrm{N}_{45}\right.$ and $\left.\mathrm{P}_{37.5} \mathrm{~kg} / \mathrm{ha}\right), \mathrm{F}_{2}\left(\mathrm{~N}_{60}\right.$ and $\left.\mathrm{P}_{50} \mathrm{~kg} / \mathrm{ha}\right)$ and $\mathrm{F}_{3}\left(\mathrm{~N}_{75}\right.$ and $\left.\mathrm{P}_{62.5} \mathrm{~kg} / \mathrm{ha}\right)$. The quality of coriander seeds harvested from various irrigation and fertilizer treatments was evaluated in Seed Testing Laboratory.

Observations were recorded on standard germination, seedling length, seedling dry weight, seedling vigour index-I, seedling vigour index-II, seed density and electrical conductivity. The standard germination (\%) was recorded by placing fifty seeds of each treatment in each replication between the germination papers at a temperature of $25 \pm 1^{\circ} \mathrm{C}$ with $90-95 \%$ relative humidity in germinator.

First germination count was taken six days after sowing and final count was taken 21 days after sowing. The observations recorded for seed germination were later converted into percent seed germination. Seedling length (cm) was calculated by measuring the total root and shoot length of ten randomly selected seedlings from each treatment in each replication at the time of termination of germination test and averaged. Seedling dry weight $(\mathrm{g})$ of ten randomly selected seedlings from each treatment in each replication was measured and averaged. Seedling vigour index-1 was calculated by the formula given by Abdul-Baki and Anderson (1973) as-

Seedling vigour index-I $=$ Average length of seedling $\mathrm{x}$ Seed germination percentage

Also, Seedling vigour index-II was calculated by the formula given by Abdul-Baki and Anderson (1973) as-
Seedling vigour index-II = Average dry weight of seedling $\mathrm{x}$ Seed germination percentage

Electrical conductivity test was conducted by soaking fifty normal and uninjured seeds in three replications for 24 hour at $25^{\circ} \mathrm{C}$ temperature. The electrical conductivity of seed leachates was measured using a Direct Reading Conductivity Meter and the conductivity was expressed in $\mu \mathrm{S} \mathrm{cm}^{-1}$ seed $^{-1}$. For measuring the seed density $(\mathrm{g} / \mathrm{cc})$, fifty seeds from each sample were taken and weighed on electrical balance. These seeds were dipped in hexane solution, having the density 0.655 . Volume of hexane displaced by the seeds was recorded and seed density was calculated by using the following formula-

Seed density $=$

$$
\text { Weight of } 50 \text { seeds (g) }
$$

Volume of hexane displaced by seeds $\left(\mathrm{cm}^{3}\right)$

\section{Results and Discussion}

\section{Effect of irrigation}

The irrigation schedules significantly affected the quality parameters viz., standard germination, seedling length, seedling dry weight, vigour index-I, vigour index-II and seed density in coriander, which increased significantly with the increase in irrigation level. The maximum standard germination $(84.18 \%)$, seedling length $(21.01 \mathrm{~cm})$, seedling dry weight $(31.40 \mathrm{mg})$, seedling vigour index-I (1770), seedling vigour indexII (2643.9) and seed density $(0.679 \mathrm{~g} / \mathrm{cc})$ were obtained under irrigation schedule 25, 50, 75 and 100 DAS $\left(\mathrm{I}_{4}\right)$ (Table 1). This might be due to more absorption of water by plant roots in frequently irrigated treatments as a result the plant maintained higher leaf water potential, better stomatal conductance and thereby high transpiration to keep the plant canopy temperature low, which led to higher production of carbohydrates due to the opening 
of stomata for longer period and their translocation to coriander fruits. Consequently, the coriander seeds were better in all quality traits. However, the electrical conductivity decreased significantly with the increase in irrigation level. The minimum electrical conductivity $\left(0.427 \mu \mathrm{S} \quad \mathrm{cm}^{-1}\right.$ seed $\left.^{-1}\right)$ was obtained under irrigation schedule 25, 50, 75 and 100 DAS $\left(\mathrm{I}_{4}\right)$ (Table 1).
The results of present study confirms the results of Singh et al., (2002a) who reported pronounced effect of irrigation on quality parameters in coriander, but contradict to the findings of Yadav et al., (1998) who observed that irrigation schedule did not influence seed quality character like germination percentage and electrical conductivity in fennel.

Table.1 Effect of irrigation and fertilizer levels on seed quality parameters of coriander

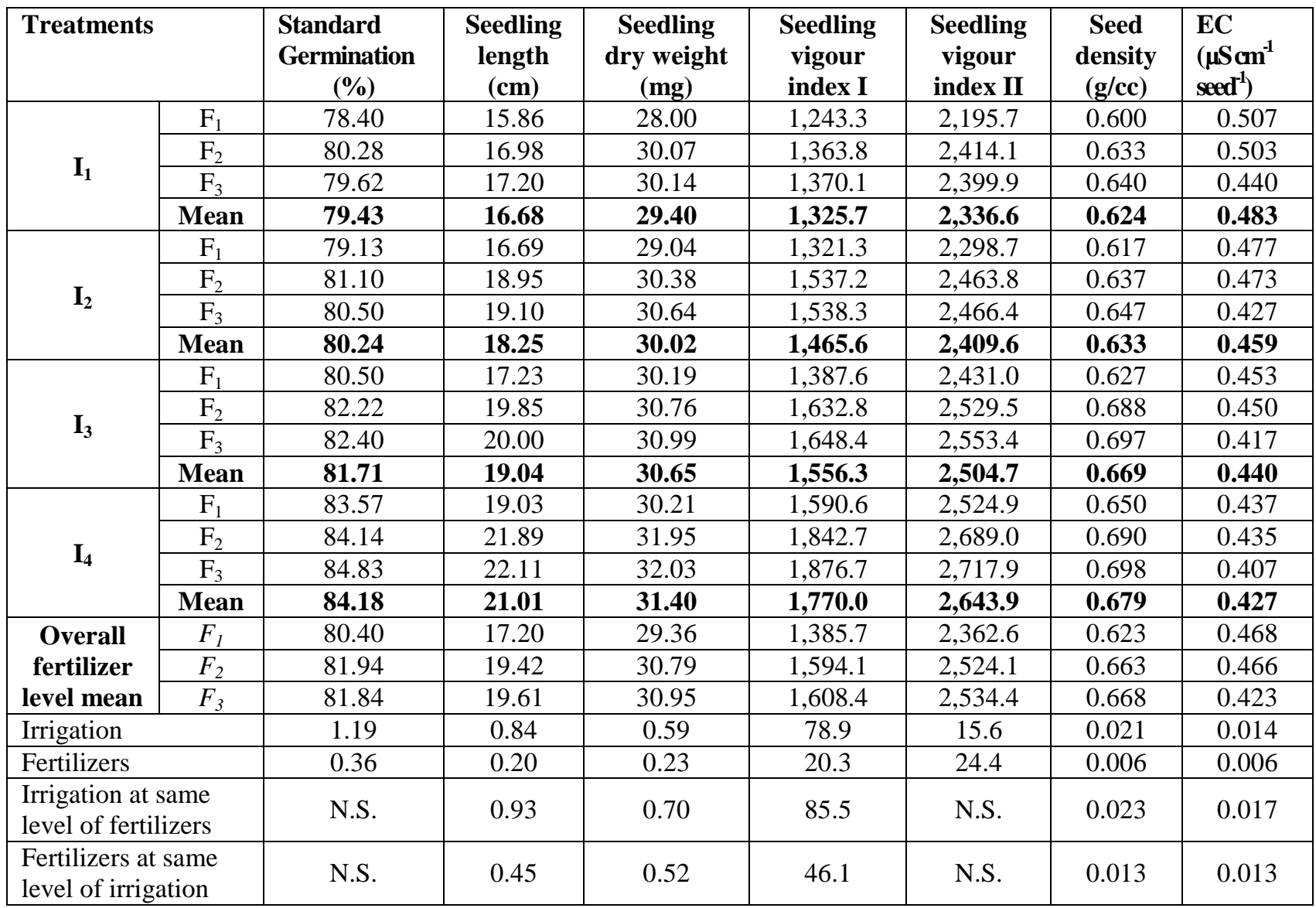

$\mathrm{I}_{1}=$ Irrigation at $25 \& 50 \mathrm{DAS} ; \mathrm{I}_{2}=$ Irrigation at $25,50 \& 75 \mathrm{DAS}, \mathrm{I}_{3}=$ Irrigation at $25,75 \& 100 \mathrm{DAS}$ and $\mathrm{I}_{4}=$

Irrigation at 25, 50, $75 \& 100 \mathrm{DAS}, \mathrm{F}_{1}=\mathrm{N}_{45}+\mathrm{P}_{37.5 \mathrm{~kg} / \mathrm{ha}}, \mathrm{F}_{2}=\mathrm{N}_{60}+\mathrm{P}_{50 \mathrm{~kg} / \mathrm{ha}}$ and $\mathrm{F}_{3}=\mathrm{N}_{75}+\mathrm{P}_{62.5 \mathrm{~kg} / \mathrm{ha}}$

\section{Effect of fertilizers}

Application of fertilizers significantly improved the quality parameters, which increased significantly with the increase in fertilizer levels only up to $\mathrm{N}_{60}+\mathrm{P}_{50} \mathrm{~kg} / \mathrm{ha}\left(\mathrm{F}_{2}\right)$. Among the fertilizer treatments, the maximum standard germination $(81.84 \%)$, seedling length $(19.42$ $\mathrm{cm}$ ), seedling dry weight $30.79 \mathrm{mg}$, seedling vigour index-I (1594.1), seedling vigour indexII (2524.1) and seed density (0.663 g/cc) was recorded under fertilizer treatment $\mathrm{N}_{60}+\mathrm{P}_{50}$ $\mathrm{kg} / \mathrm{ha}\left(\mathrm{F}_{2}\right)$, which was at par with fertilizer treatment $\mathrm{N}_{75}+\mathrm{P}_{62.5} \mathrm{~kg} / \mathrm{ha}\left(\mathrm{F}_{3}\right)$. However, the electrical conductivity decreased with the increase in fertilizer level (Table 1). The 
minimum electrical conductivity $\left(0.423 \mu \mathrm{S} \mathrm{cm}^{-1}\right.$ seed $^{-1}$ ) was recorded under fertilizer treatment $\mathrm{N}_{75}+\mathrm{P}_{62.5} \mathrm{~kg} / \mathrm{ha}\left(\mathrm{F}_{3}\right)$, while the maximum electrical conductivity $\left(0.468 \mu \mathrm{S} \mathrm{cm} \mathrm{cm}^{-1} \mathrm{seed}^{-1}\right)$ was obtained with fertilizer treatment $\mathrm{N}_{45}+\mathrm{P}_{37.5}$ $\mathrm{kg} / \mathrm{ha}\left(\mathrm{F}_{1}\right)$, which was statistically at par with fertilizer treatment $\mathrm{N}_{60}+\mathrm{P}_{50} \mathrm{~kg} / \mathrm{ha}\left(\mathrm{F}_{2}\right)$, i.e., $0.466 \mu \mathrm{S} \mathrm{cm}^{-1}$ seed $^{-1}$ (Table 1).

This might be due to better supply of nutrients to the plant, which led to higher production of carbohydrates and their translocation to coriander fruits. As a result, the semi-permeable membrane was strong enough not to allow the movement of leachates out of the fruit.

\section{Interaction effect of irrigation and fertilizers}

The interaction effect of irrigation at same level of fertilizers and of fertilizers at same level of irrigation was found significant for seedling length, seedling dry weight, seedling vigour index-I, seed density and electrical conductivity. The maximum seedling length $(22.11 \mathrm{~cm})$, seedling dry weight $(32.03 \mathrm{mg})$, seedling vigour index-I (1876.7) and seed density $(0.698 \mathrm{~g} / \mathrm{cc})$ was recorded under irrigation schedule 25, 50, 75 and 100 DAS $\left(\mathrm{I}_{4}\right)$ in combination with fertilizer treatment $\mathrm{N}_{75}+$ $\mathrm{P}_{62.5} \mathrm{~kg} / \mathrm{ha}\left(\mathrm{F}_{3}\right)$, followed by same irrigation schedule coupled with fertilizer treatment $\mathrm{N}_{60}+$ $\mathrm{P}_{50} \mathrm{~kg} / \mathrm{ha}\left(\mathrm{F}_{2}\right)$, i.e., $21.89 \mathrm{~cm}, 31.95 \mathrm{mg}, 1842.7$ and $0.690 \mathrm{~g} / \mathrm{cc}$, respectively (Table 1).

The minimum electrical conductivity $(0.407 \mu \mathrm{S}$ $\mathrm{cm}^{-1}$ seed $^{-1}$ ) was recorded under irrigation schedule 25, 50, 75 and 100 DAS $\left(\mathrm{I}_{4}\right)$ in combination of fertilizer treatment $\mathrm{N}_{75}+\mathrm{P}_{62.5}$ $\mathrm{kg} / \mathrm{ha}\left(\mathrm{F}_{3}\right)$, followed by same irrigation schedule coupled with fertilizer treatment $\mathrm{N}_{60}+\mathrm{P}_{50} \mathrm{~kg} / \mathrm{ha}$ $\left(\mathrm{F}_{2}\right)$, i.e., $0.435 \mu \mathrm{S} \mathrm{cm}^{-1}$ seed $^{-1}$.

\section{References}

Anonymous, 2015. Area, production and productivity of spices. Directorate of Arecanut and Spices Development, Ministry of agriculture, Government of India, Calicut, Kerala.

Carrubba, A., 2009. Nitrogen fertilization in coriander (Coriandrum sativum L.): A review and meta-analysis. Journal of the Science of Food and Agriculture, 89: 921926.

Hassan, F.A.S. and Ali, E.F., 2013. Impact of different water regimes based on class-A pan on growth, yield and oil content of Coriandrum sativum L. plant. Journal of the Saudi Society of Agricultural Sciences, 13: 155-161.

Mahendra, P. and Bisht, S., 2011. Coriandrum sativum: a daily use spice with great medicinal effect. Pharmacognosy Journal, 21(3): 84-88.

Ramadan, F.M. and Morsel, J.T., 2002. Oil composition of coriander (Coriandrum sativum L.) fruit-seeds. European Food Research Technology, 215: 204-209.

Sahib, N.G., Anwer, F., Gilani, A.H., Hamid, A.A., Saari, N. and Alkharfy, K.M., 2013. Coriandrum sativum: a potential source of high value components for functional food and nutraceuticals- a review. Phytotheoretical Research, 27: 14391456.

Singh, V.P., Yadav, A.C. and Thakral, K.K., 2002a. Effect of irrigation and weed control treatment on yield and quality of coriander seed. Seed Research, 30(2): 328-330.

Yadav, A.C., Batra, B.R. and Malik, Y.S., 1998. Irrigation requirement of fennel. Proceedings of the National Seminar held at Madikeri from 5-7 October, 1997.

\section{How to cite this article:}

Harshita Singh, V.P.S. Panghal, V.S. Mor and Rana, M.K. 2017. Seed Quality of Coriander as Affected by Irrigation and Fertilizer Levels. Int.J.Curr.Microbiol.App.Sci. 6(12): 81-84.

doi: https://doi.org/10.20546/ijcmas.2017.612.010 